\title{
Sistem Pendukung Keputusan Penerimaan Karyawan Menggunakan Metode SAW (Studi Kasus di PT. Nusantara Sakti Ciptadana Finance Kota Bengkulu)
}

\author{
Yupianti ${ }^{1}$, Sinta Puspita Sari ${ }^{2}$ \\ ${ }^{1,2}$ Program Studi Teknik Informatika, Universitas Dehasen Bengkulu \\ Email : yupiantiprana@gmail.com
}

\begin{abstract}
The method used in this research was system development method. To collect data, interview and literature study was conducted. The software used to build the system was Visual Basic 6.0 and the results obtained were able to provide quick and accurate output. The results of this research was Decision Support System for Employees Recruitment. The system consist of five criteria, namely input for applicants, input for data criteria of administrative completeness, input for criteria of computer practice examination, input for written test criteria, input for weighting criteria, and data input for determining Final Calculation Value of Simple Additive Weight. There were also two reports, namely individual reports and rank reports. From the results of research, it can be concluded that the Decision Support System for Employees Recruitment at PT. Nusantara Sakti Ciptadana (NSC) Finance Kota Bengkulu Using SAW Method, were more efficient, complete and accurate.
\end{abstract}

Keyword : Decision Support System, Simple Additive Weighting, SAW

Intisari-Metode yang digunakan dalam penelitian ini adalah metode pengembangan sistem dan metode pengumpulan data yang digunakan dalam penelitian ini adalah wawancara dan studi pustaka. Perangkat lunak yang digunakan untuk membangun sistem Pemrograman Visual Basic 6.0 dan hasil yang diperoleh yaitu dapat memberikan output secara cepat dan tepat. Hasil yang didapat dari penelitian ini adalah berupa Sistem Pendukung Keputusan Penerimaan Karyawan. Dari system terdapat lima buah input yaitu input pelamar, input data kriteria kelengkapan administrasi, input data kriteria test praktik komputer, input data kriteria test tertulis, input data bobot kriteria, dan input data proses penentuan nilai akhir perhitungan SAW. Terdapat juga dua laporan yaitu laporan perorangan dan laporan perankingan. Dari hasil pembahasan, dapat ditarik kesimpulan bahwa Sistem Pendukung Keputusan Pene- rimaan Karyawan pada PT. Nusantara Sakti Ciptadana (NSC) Finance Kota Bengkulu Menggunakan Metode SAW, lebih efisien, lengkap dan akurat.

Kata Kunci : Sistem Pendukung Keputusan, Simple Additive Weighting, SAW

\section{PENDAHULUAN}

Kemajuan teknologi informasi pada saat ini telah mampu membantu manusia dalam mengambil keputusan. Hal tersebut dimungkinkan karena perkembangan teknologi komputer yang semakin pesat, baik disegi perangkat kerasnya maupun disegi perangkat lunaknya. Oleh karena itu komputer merupakan salah satu sarana yang tepat untuk membantu pengambilan keputusan pada proses Penerimaan karyawan.

PT. Nusantara Sakti Ciptadana (NSC Finance) adalah perusahaan yang bergerak pembiayaan dan penjualan sepeda motor serta service sepeda Motor. Dalam penyeleksian pelamar PT. Nusantara Sakti Ciptadana (NSC Finance) biasanya memberikan beberapa persyaratan atau kriteria untuk mengetahui kemampuan serta pribadi pelamar tersebut, data hasilnya tersebut biasanya disimpan dalam suatu arsip pelamar yang harus dibandingkan satu persatu sehingga didapatkan hasil keputusan. Tentu hal tersebut memakan waktu yang lama dan kurang efektif.

Tujuan penelitian ini adalah membangun Metode SAW yang dapat di akses oleh operator pada PT. Nusantara Sakti Group (NSC Finance) Kota Bengkulu. Manfaat yang didapatkan adalah 
mempermudah proses penilaian terhadap penerimaan karyawan sehingga hasilnya lebih tepat dan akurat karena didasarkan pada nilai kriteria dan bobot yang sudah ditentukan.

\section{TINJAUAN PUSTAKA}

\section{A. Sistem Pendukung Keputusan}

Decision Support System atau Sistem Pendukung Keputusan menurut Julius (2005:1) adalah "sebagai sebuah sistem yang mampu memberikan kemampuan pengkomunikasian untuk masalah semi terstruktur".

Dari definisi tersebut bisa disimpulkan bahwa tujuan Sistem pendukung Keputusan dalam proses pengambilan keputusan adalah :

1. Membantu menjawab masalah semi-terstruktur

2. Membantu manajer dalam mengambil keputusan, bukan mengantikannya.

3. Manajer yang dibantu melingkupi top manajer sampai manajer lapangan

4. Fokus pada keputusan yang efektif, bukan keputusan yang efisien.

\section{B. Proses Pengambilan Keputusan}

Tahap-tahap proses pengambilan keputusan adalah sebagai berikut.

\section{1) Tahap Intelegence}

Dalam tahap ini pengambil keputusan mempelajari kenyataan yang terjadi sehingga kita bisa mengindefitikasi dan mendefinisikan masalah yang sedang terjadi, biasanya dilakukan analisis berurutan dari sistem ke subsistem pembentuknya. Dari tahap ini didapatkan keluaran berupa dokumen pernyataan masalah.

\section{2) Tahap Design}

Dalam tahap ini pengambil keputusan mengemukakan, mengembangkan, dan menganalisis semua pemecahan yang mungkin, yaitu melalui pembuatan model yang bisa mewakili kondisi nyata masalah. Dari tahap ini didapatkan keluaran berupa dokumen Alternatif Solusi.

\section{3) Tahap Choice}

Dalam tahap ini mengambil keputusan memilih salah satu alternatif pemecahan yang dibuat pada tahap Design yang dipandang sebagai aksi yangpaling tepat untuk mengatasi masalah yang sedang dihadapi. Dari tahap ini didapatkan keluaran berupa dokumen Solusi dan Rencana Implementasinya.

\section{4) Tahap Implementasion}

Dalam tahap ini mengambil keputusan menjalankan rangkaian aksi pemecahan yang dipilih di tahap choice. Implementasi yang sukses ditandai dengan terjawabnya masalah yang dihadapi, sementara kegagalan ditandai dengan tetap adanya masalah yang sedang dicoba untuk diatasi. Dari tahap ini didapatkan keluaran berupa laporan pelaksanaan solusi dan hasilnya.

\section{Metode Simple Additive Weighthing (SAW)}

Menurut Fishburn, (1967) dan MacCrimmon (1968) yang dikutip lagi oleh Sri Kusumadewi dkk, (2006:74) Metode SAW atau sering juga dikenal istilah metode penjumlahan terbobot adalah "mencari penjumlahan terbobot dari ranting kinerja pada setiap alternative pada semua atribut".

Metode SAW membutuhkan proses normalisasi matrik keputusan (X) ke skala yang dapat diperbandingkan dengan semua rating alternative yang ada.

$\mathrm{R}_{\mathrm{ij}}= \begin{cases}\frac{x_{i j}}{\operatorname{Maxx_{ij}}} & \text { Jika } \mathrm{j} \text { adalah atribut keuntungan (benetif) } \\ \frac{}{\operatorname{Minx}_{i j}} & \text { Jika } \mathrm{j} \text { adalah atribut biaya (cost) }\end{cases}$

Dimana $r_{i j}$ adalah rating kinerja ternormalisasi dari alternative $A_{i}$ pada atribut $C_{j} ; I=1,2, \ldots, m$ dan $\mathrm{j}=1,2, \ldots, \mathrm{n}$ Nilai preferensi untuk setiap alternative $\left(\mathrm{V}_{\mathrm{i}}\right)$ diberikan sebagai :

$$
V_{i}=\sum_{j=1}^{n} w_{j} r_{i j}
$$


Nilai $\mathrm{V}_{\mathrm{i}}$ yang lebih besar mengidentifikasikan bahwa alternative $\mathrm{A}_{\mathrm{i}}$ lebih terpilih.

Langkah-langkah dalam menentukan metode SAW adalah sebagai berikut.

1. Menentukan Kriteria yang akan dijadikan acuan dalam pengambilan keputusan,misalnya $\mathrm{C} 1$.

2. Menentukan rating kecocokan setiap alternatif pada setiap kriteria

3. Membuat matriks keputusan berdasarkan kriteria (C1), kemudian melakukan normalisasi matriks berdasarkan persamaan yang disesuaikan dengan jenis atribut (atribut keuntungan ataupun atribut biaya) sehingga matriks ternormalisasi $\mathrm{R}$.

4. Hasil akhir diperoleh dari proses perankingan yaitu perjumlahan dari perkalian matriks ternormalisasi $\mathrm{R}$ dengan vector bobot preferensi sehingga diperoleh nilai terbesar yang dipilh sebagai alternatif terbaik misalnya (A1).

\section{Visual Basic 6.0}

Menurut Subari dan Susanto (2008:1) Visual Basic selain disebut sebagai bahasa pemrograman (language program), juga sering disebut sebagai sarana (Tool) untuk menghasilkan program-program aplikasi bebasis windows.

Secara umum ada beberapa manfaat yang diperoleh dari pemakaian program visual basic, antaranya :

1. Dipakai dalam membuat program-program aplikasi bebasis windows,

2. Dipakai dalam membuat obyek-obyek pembantu program seperti fasilitas help, control active, aplikasi internet, dan sebagainya,

3. Digunakan untuk menguji program (Debugging) dan menghasilkan program akhir EXE yang disebut executable, atau dapat langsung dijalankan.

\section{ANALISA DAN PERANCANGAN}

\section{A. Analisa Sistem Aktual}

Sebelum melakukan analisa lebih terhadap rencana pengembangan suatu sistem baru yang diterapkan, penulis melakukan peninjauan terhadap sistem lama, agar dapat diketahui kekurangan sistem yang di pakai pada PT. Nusantara Sakti Ciptadana (NSC Finance), karena yang selama ini terjadi khususnya pada program-program yang tidak terpusat di PT. Nusantara Sakti Ciptadana (NSC Finance) lebih banyak menggunakan cara manual dan konvensional. karena masih banyak menggunakan penyelesaian administrasi dengan menggunakan Microsoft Word dan Microsoft Excel.

Dalam mengembangkan sistem baru, Penulis akan merancang sebuah perangkat lunak atau program untuk memudahkan pekerjaan tentang sistem penerimaan karyawan baru yang berlaku pada PT. Nusantara Sakti Ciptadana (NSC Finance).

Pengembangan sistem baru diperlukan untuk mengaanalisa terhadap sistem yang sekarang digunakan pada PT. Nusantara Sakti Ciptadana (NSC Finance). Berdasarkan pemantaun penulis di lapangan, tidak ada aplikasi khusus yang digunakan untuk mengelola penerimaan karyawan baru pada PT. Nusantra Sakti Ciptadana (NSC Finance) yang merekomendasikan layak atau tidaknya diterima sebagai karyawan.

\section{B. Analisa Sistem Baru}

Pada bagian ini dijelaskan proses dari rancangan Sistem Pendukung Keputusan Penerimaan Karyawan pada PT. Nusantara Sakti Ciptadana (NSC Finance) Kota Bengkulu Menggunakan Metote SAW yang memanfaatkan teknik penerapan Metode Simple Additive Weighting dan diagram alir sistem sebagai diagram yang akan menggambarkan data logika program tersebut. Tujuan digunakannya penerapan Metode SAW dan diagram alir sistem adalah agar kejadian dalam program dapat lebih jelas, benar dan saling 
berhubungan satu sama lain. Adapun analisa yang akan dilakukan adalah : Penerapan Metode SAW, diagram kontek, DFD (Data Flow Diagram), HIPO (Hierarchy Plus Input Process), rancangan file, rancangan input dan rancangan output.

\section{Penerapan Metode Simple Additive Weigh- ting (SAW)}

Dalam penelitian ini diasumsikan bahwa akan memilih seorang calon karyawan. Dalam penerapan metode SAW ini akan dicontohkan untuk penerimaan karyawan bagian Administrasi dengan tiga kriteria yang digunakan untuk melakukan penilaian, yaitu :

$$
\begin{aligned}
& \mathrm{C} 1=\text { Seleksi Administrasi } \\
& \mathrm{C} 2=\text { Test Praktik Komputer } \\
& \mathrm{C} 3=\text { Test Tertulis }
\end{aligned}
$$

Nilai untuk setiap alternative (Vi) diberikan sebagai :

$$
V_{i}=\sum_{j=1}^{n} w_{j} r_{i j}
$$

Nilai $V_{i}$ yang lebih besar mengidentifikasikan bahwa alternatif $\mathrm{A}_{\mathrm{i}}$ lebih terpilih.

Pengambilan keputusan memberikan bobot untuk setiap kriteria sebagai berikut : $w 1=20$, $\mathrm{w} 2=20, \mathrm{w} 3=60$.

Misalkan ada 5 (lima) orang yang mengikuti seleksi calon karyawab dengan data sebagai berikut :

$$
\begin{aligned}
& \text { A1 }=\text { Muhammad Ali Akbar } \\
& \text { A2 }=\text { Mey Santi } \\
& \text { A3 }=\text { Indra Kusuma } \\
& \text { A4 }=\text { Pen Kusuma } \\
& \text { A5 }=\text { Gilang Ramadhan }
\end{aligned}
$$

Ranting Kecocokan setiap alternatif pada setiap kriteria, dinilai dengan 1 sampai 5, yaitu :

$1=$ Sangat Buruk,

$2=$ Buruk,

$3=$ Cukup,

$4=$ Baik,

5 =Sangat Baik

Tabel 1. menunjukan ranting dari setiap alternatif kecocokan pada alternatif yaitu setiap krite- ria Sedangkan tingkat kepentingan setiap kriteria juga dinilai dengan 1 sampai 5 yaitu :

\section{1) Alternatif/Kriteria Seleksi Administrasi}

- Ijazah, Pengelaman Kerja, Sertifikat (Nilai 5)

- Ijazah, Pengalaman Kerja, tidak meiliki Sertifikat (Nilai 4)

- Ijazah, Tidak memiliki Pengelaman Kerja, Serifikat (Nilai 3)

- Ijazah, Tidak memiliki pengalaman kerja, tidak memiliki sertifikak (Nilai 2)

- Ijazah tidak sesuai, tidak memiliki pengalaman kerja, tidak memiliki sertifikat. (Nilai 1)

\section{2) Alternatif/Kriteria Test Kompuer}

- 90\% - $100 \%$ Menguasai Test Praktik Komputer (Nilai 5)

- $75 \%-89 \%$ Menguasai Test Praktik Komputer (Nilai 4)

- $50 \%-74 \%$ Menguasai Test Praktik Komputer (Nilai 3)

- $25 \%$ - 49\% Menguasai Test Parktik Komputer (Nilai 2)

- $0 \%-25 \%$ Menguasai Test Praktik Komputer (Nilai 1)

\section{3) Alternatif/ Test Tertulis (50 Soal)}

- Jawaban Bernar 46 - 50 (Nilai 5)

- Jawabab Benar 40 - 45 (Nilai 4)

- Jawaban Benar 35 - 39 (Nilai 3)

- Jawaban Benar 30 - 34 (Nilai 2)

- Jawbaan Bemar 5-29 (Nilai 1)

Tabel 1. Rating Kecocokan dari setiap Alternatif pada setiap Kriteria

\begin{tabular}{|l|c|c|c|}
\hline \multirow{2}{*}{ Alternatif } & \multicolumn{3}{|c|}{ Kriteria } \\
\cline { 2 - 4 } & C1 & C2 & C3 \\
\hline A1 & 5 & 4 & 4 \\
\hline A2 & 4 & 5 & 3 \\
\hline A3 & 5 & 3 & 3 \\
\hline A4 & 3 & 4 & 3 \\
\hline A5 & 5 & 3 & 3 \\
\hline
\end{tabular}

Dari tabel kecocokan tersebut maka dapat dibentuk matriks keputusan sebagai berikut : 


$$
X=\left[\begin{array}{lll}
5 & 4 & 4 \\
4 & 5 & 3 \\
5 & 3 & 3 \\
3 & 4 & 3 \\
5 & 3 & 3
\end{array}\right]
$$

Selanjutnya dilakukan normalisasi matriks X dengan rumus sebagai berikut :

$\mathrm{R}_{\mathrm{ij}}=\left\{\begin{array}{c}\frac{x_{i j}}{\text { Max } x_{i j}} \text { jika } j \text { adalah atribut keuntungan (benefit) } \\ \frac{\text { Min } x_{i j}}{x_{i j}} \text { jika } j \text { adalah atribut biaya }(\text { Cost })\end{array}\right\}$

Perhitungan Normalisasi matriks $\mathrm{X}$ :

$$
\begin{aligned}
& \mathrm{R}_{11}=\frac{5}{\max (5,4,5,3,5)}=\frac{5}{5}=1,00 \\
& \mathrm{R}_{21}=\frac{4}{\max (5,4,5,3,5)}=\frac{4}{5}=0,80 \\
& \mathrm{R}_{31}=\frac{5}{\max (5,4,5,3,5)}=\frac{5}{5}=1,00 \\
& \mathrm{R}_{41}=\frac{3}{\max (5,4,5,3,5)}=\frac{3}{5}=0,60 \\
& \mathrm{R}_{51}=\frac{5}{\max (5,4,5,3,5)}=\frac{5}{5}=1,00 \\
& \mathrm{R}_{12}=\frac{4}{\max (4,5,3,4,3)}=\frac{4}{5}=0,80 \\
& \mathrm{R}_{22}=\frac{4}{\max (4,5,3,4,3)}=\frac{5}{5}=1,00 \\
& \mathrm{R}_{32}=\frac{5}{\max (4,5,3,4,3)}=\frac{3}{5}=0,60 \\
& \mathrm{R}_{42}=\frac{3}{\max (4,5,3,4,3)}=\frac{4}{5}=0,80 \\
& \mathrm{R}_{52}=\frac{5}{\max (4,5,3,4,3)}=\frac{3}{5}=0,60 \\
& \mathrm{R}_{51}=\frac{4}{\max (4,3,3,3,3)}=\frac{4}{5}=0,80 \\
& \mathrm{R}_{13}=\frac{3}{\max (4,3,3,3,3)}=\frac{3}{5}=0,60 \\
& \mathrm{R}_{23}=\frac{3}{\max (4,3,3,3,3)}=\frac{3}{5}=0,60 \\
& \mathrm{R}_{33}=\frac{3}{\max (4,3,3,3,3)}=\frac{3}{5}=0,60 \\
& \mathrm{R}_{43}=\frac{3}{\max (4,3,3,3,3)}=\frac{3}{5}=0,60 \\
& \mathrm{R}_{53}=\frac{3}{\max (4,3,3,3,3)}=\frac{3}{5}=0,60
\end{aligned}
$$

Hasil normalisasi

$$
R=\left[\begin{array}{lll}
1,00 & 0,80 & 0,80 \\
0,80 & 1,00 & 0,60 \\
1,00 & 0,60 & 0,60 \\
0,60 & 0,80 & 0,60 \\
1,00 & 0,60 & 0,60
\end{array}\right]
$$

Proses perangkingan dengan menggunakan bobot yang telah diberikan oleh pengambil keputusan :

$$
\mathrm{W}=\left[\begin{array}{lll}
0,20 & 0,20 & 0,60)
\end{array}\right.
$$

Hasil yang diperoleh adalah sebagai berikut :

$$
\begin{aligned}
\mathrm{V}_{1} & =(0,20)(1,00)+(0,20)(0,80)+(0,60)(0,80) \\
& =0,84 \\
\mathrm{~V}_{2} & =(0,20)(0,80)+(0,20)(1,00)+(0,60)(0,60) \\
& =0,72 \\
\mathrm{~V}_{3} & =(0,20)(1,00)+(0,20)(0,60)+(0,60)(0,60) \\
& =0,68 \\
\mathrm{~V}_{4} & =(0,20)(0,60)+(0,20)(0,80)+(0,60)(0,60) \\
& =0,64 \\
\mathrm{~V}_{5} & =(0,20)(1,00)+(0,20)(0,60)+(0,60)(0,60) \\
& =0,68
\end{aligned}
$$

Nilai terbesar ada pada $\mathrm{V}_{1}$ sehingga alternatif $A_{1}$ adalah alternatif yang terpilih sebagai alternatif yang terbaik.

Dengan kata, lain Muhammad Ali Akbar akan terpilih sebagai calon Karyawan urutan rangking teratas diikuti oleh Mey Santi, Indra Kusuma, Gilang Ramadhan dan Pen Kusuma.

\section{Diagram Alir Data (Data Flow Diagram) \\ 1) Diagram Konteks}

Diagram konteks yang menggambarkan Sistem Informasi Peminjaman pada PT. Nusantra Sakti Ciptadana (NSC Finance) Bengkulu secara umum ditunjukkan pada Gambar 1.

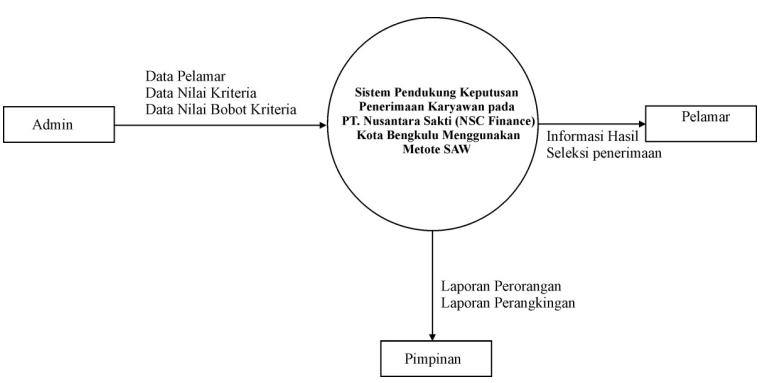

Gambar 1. Diagram Konteks 


\section{2) Diagram Level 0}

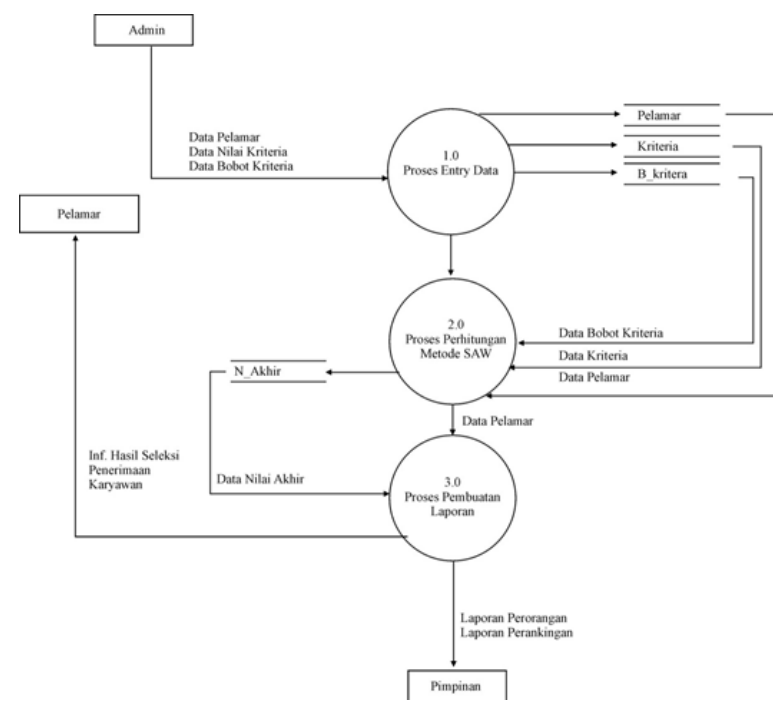

Gambar 2. Diagram Level 0

\section{3) Diagram Level 1}

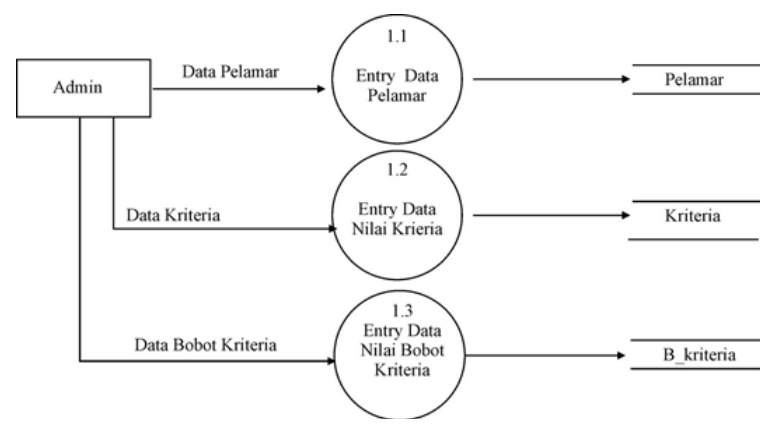

Gambar 3. Diagram Level 1 (Proses Entry Data)

\section{4) Diagram Level 2}

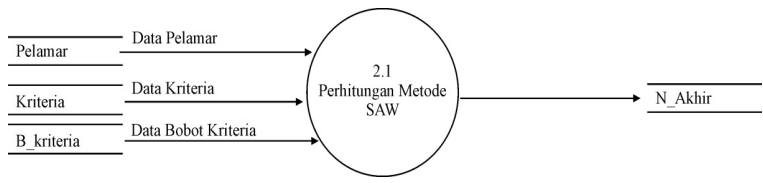

Gambar 4. Diagram Level 2 (Proses Perhitungan Metode SAW)

\section{5) Diagram Level 3}

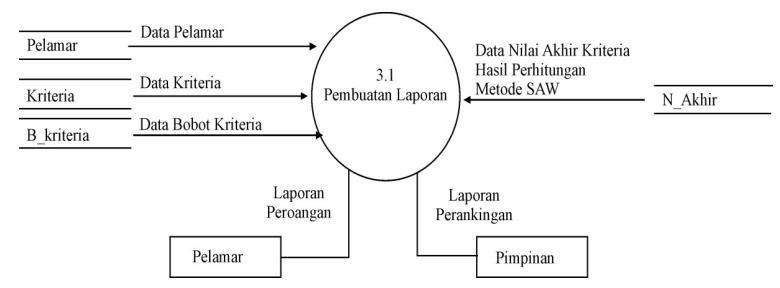

Gambar 5. Diagram Level 3 (Proses Pembuatan Laporan)

\section{E. ERD (Entity Relationship Diagram)}

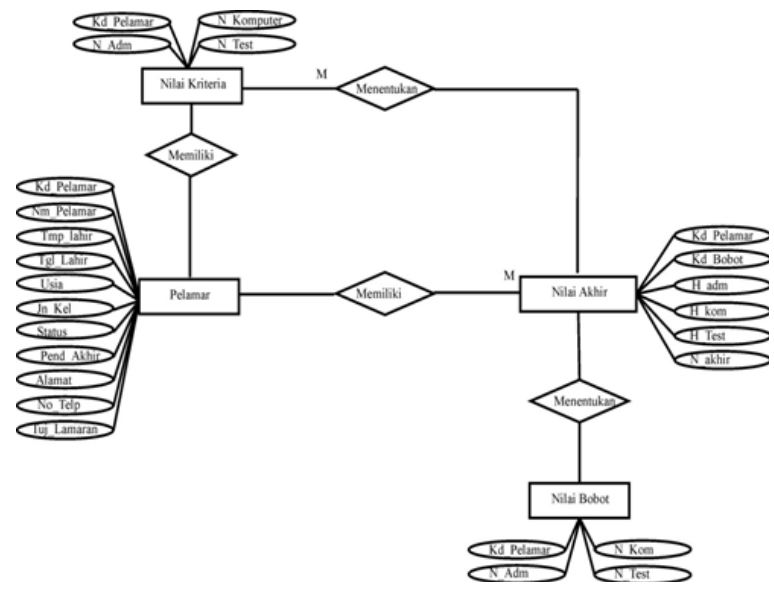

Gambar 6. ERD (Entity Relationship Diagram)

\section{F. Rancangan Menu}

\section{1) Rancangan Menu Utama}

Menu utama merupakan menu untuk melakukan pilihan pekerjaan yang akan dilakukan.

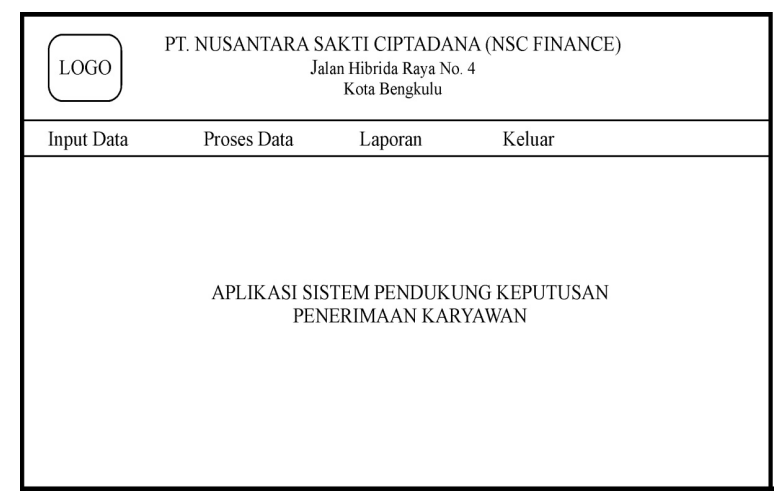

Gambar 7. Rancangan Menu Utama

\section{2) Rancangan Menu Input Data}

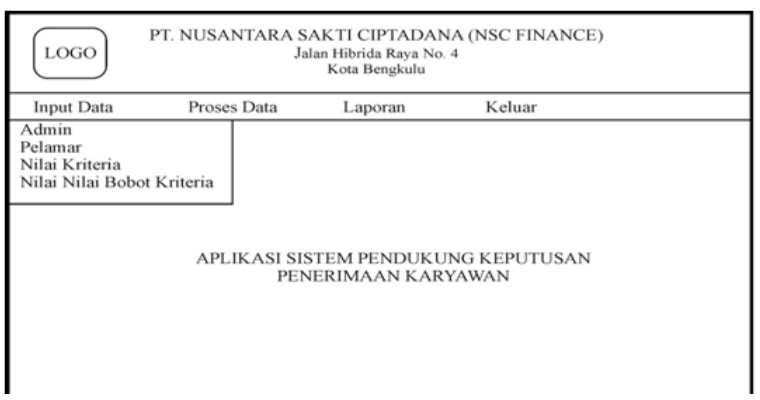

Gambar 8. Rancangan Menu Input Data

Rancangan Menu Input terdiri atas menu input data admin, menu input data pelamar dan rancangan menu input data penilaian kriteria. 


\section{a) Rancangan Form Menu Input Admin}

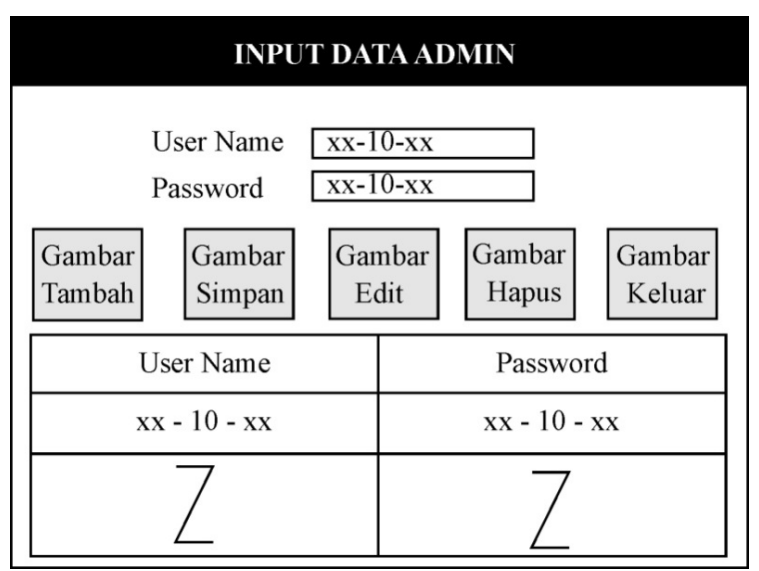

Gambar 9. Rancangan Form Input Data Admin

\section{b) Rancangan Input Data Pelamar}

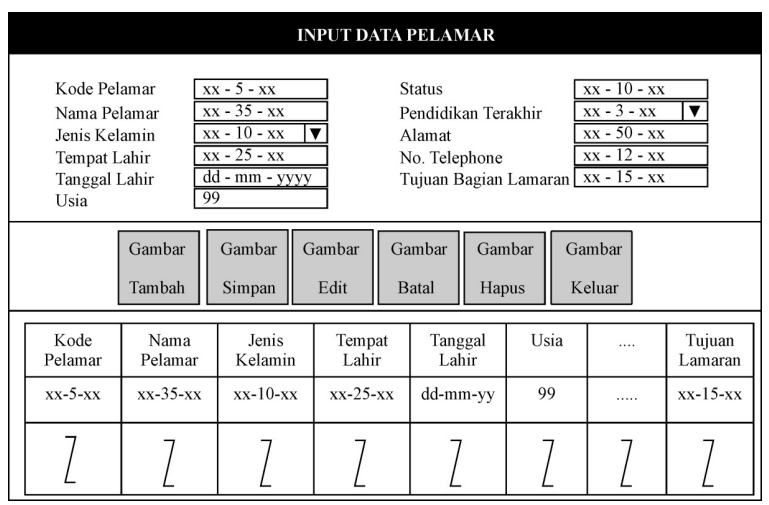

Gambar 10. Rancangan Input Data Pelamar

\section{c) Rancangan Input Data Nilai Kriteria}

Input data nilai kriteria terdiri dari Input kriteria seleksi administrasi, input data kriteria test komputer dan input data kriteria test tertulis. Untuk memulai memasukkan nilai kriteria diberikan menu pilihan seperti terlihat pada Gambar 11.

\section{PILIHAN INPUT DATA NILAI KRITERIA}

o Input Data Kelengkapan Administrasi

o Input Data Test Komputer

o Input Data Nilai Test Tertulis

Gambar 11. Pilihan Input Data Nilai Kriteria

\section{d) Input Data Nilai Kriteria Kelengkapan Ad- ministrasi}

\section{INPUT DATA NILAI KRITERIA KELANGKAPAN ADMINISTRASI}

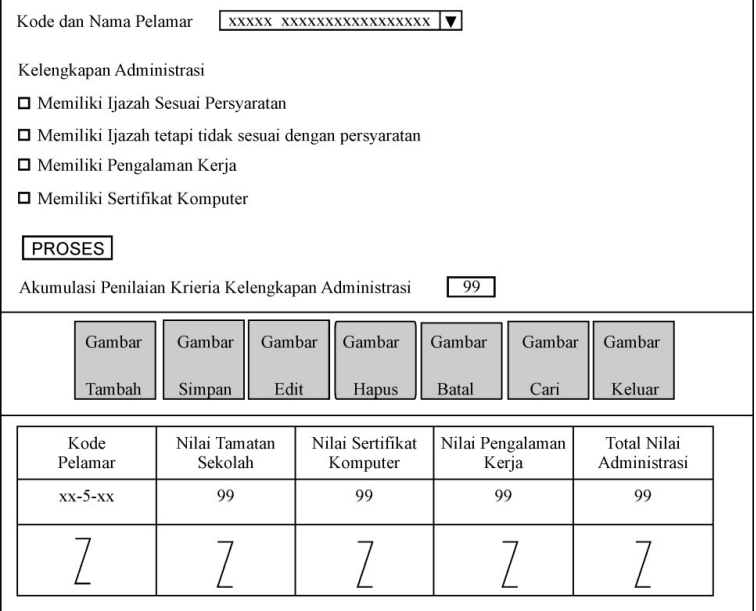

Gambar 12. Input Data Nilai Kriteria Kelengkapan Administrasi

e) Input Data Nilai Krieria Test Praktik Komputer

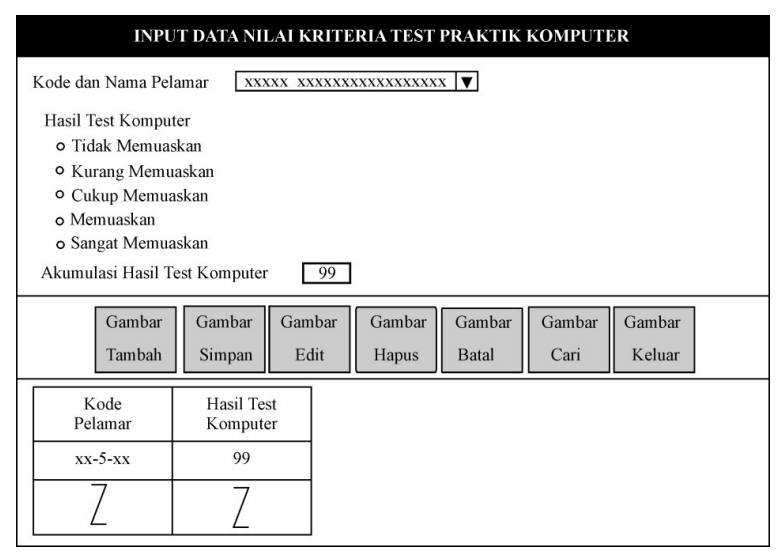

Gambar 13. Input Data Nilai Kriteria Test Komputer

\section{f) Input Data Nilai Krieria Test Tertulis}

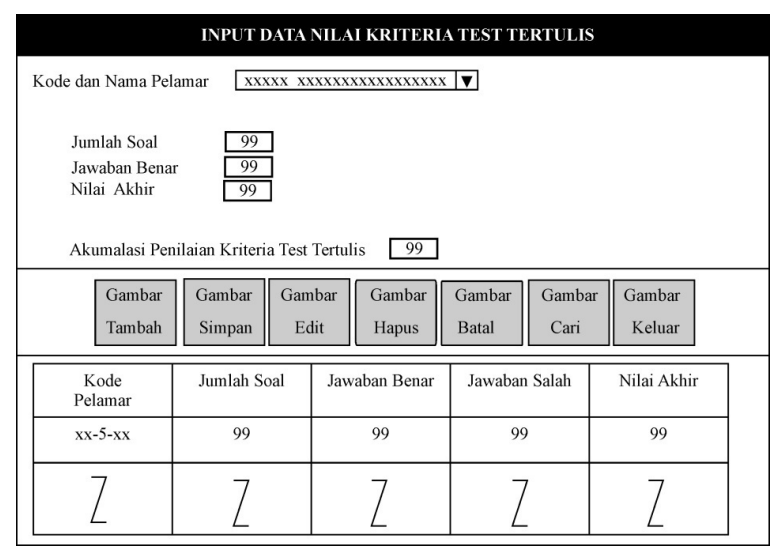

Gambar 14.Input Data Nilai Kriteria Test Tertulis 


\section{g) Rancangan Input Data Bobot Kriteria}

\begin{tabular}{|c|c|c|c|c|c|c|}
\hline \multicolumn{7}{|c|}{ INPUT DATA NILAI BOBOT KRITERIA } \\
\hline \multirow{4}{*}{\multicolumn{2}{|c|}{$\begin{array}{l}\text { Nilai Bobot Kriteria } \\
\text { Seleksi Administrasi } \\
\text { Test Praktik Komputer } \\
\text { Test Tertulis }\end{array}$}} & \multirow{4}{*}{\multicolumn{3}{|c|}{$\begin{array}{l}\text { Prosentase } \\
\begin{array}{|l|}99 \\
99 \\
99 \\
\end{array}\end{array}$}} & \multirow{4}{*}{\multicolumn{2}{|c|}{$\begin{array}{l}\text { Normalisasi } \\
\begin{array}{|l|}99 \\
99 \\
99 \\
99\end{array}\end{array}$}} \\
\hline & & & & & & \\
\hline & & & & & & \\
\hline & & & & & & \\
\hline & $\begin{array}{l}\text { Gambar } \\
\text { Tambah }\end{array}$ & \begin{tabular}{|l|} 
Gambar \\
Simpan \\
\end{tabular} & $\begin{array}{r}\text { Gam } \\
\mathrm{Ed} \\
\end{array}$ & & $\begin{array}{l}\text { Gambar } \\
\text { Hapus } \\
\end{array}$ & $\begin{array}{r}\text { Gambar } \\
\text { Keluar } \\
\end{array}$ \\
\hline $\begin{array}{l}\text { Kode } \\
\text { Bobot }\end{array}$ & & $\begin{array}{l}\text { Jilai Bobot Sele } \\
\text { Administrasi }\end{array}$ & & $\begin{array}{l}\text { Nilai I } \\
\text { Praktik }\end{array}$ & $\begin{array}{l}\text { Bobot Test } \\
\text { Komputer }\end{array}$ & $\begin{array}{l}\text { Nilai Bobot Test } \\
\text { Tertulis }\end{array}$ \\
\hline$x x-5-x x$ & & 99 & & & 99 & 99 \\
\hline 7 & & 7 & & & 7 & 7 \\
\hline
\end{tabular}

Gambar 15. Rancangan Input Data Nilai Bobot Kriteria

\section{3) Rancangan Menu Proses}

Rancangan Menu proses merupakan proses penentuan nilai akhir kriteria dengan metode SAW.

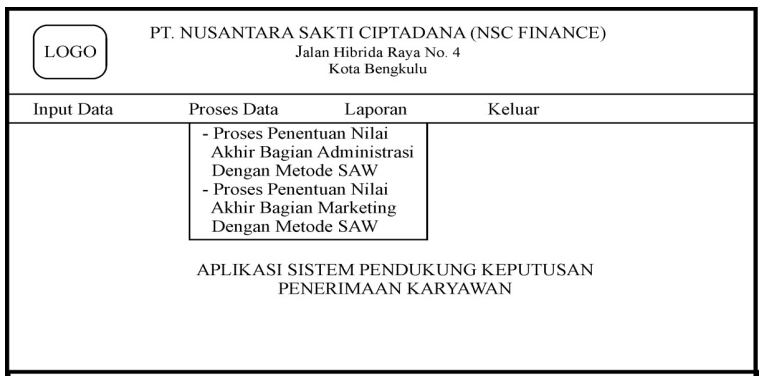

Gambar 16. Rancangan Input Proses Data

\section{4) Perhitungan Nilai Akhir}

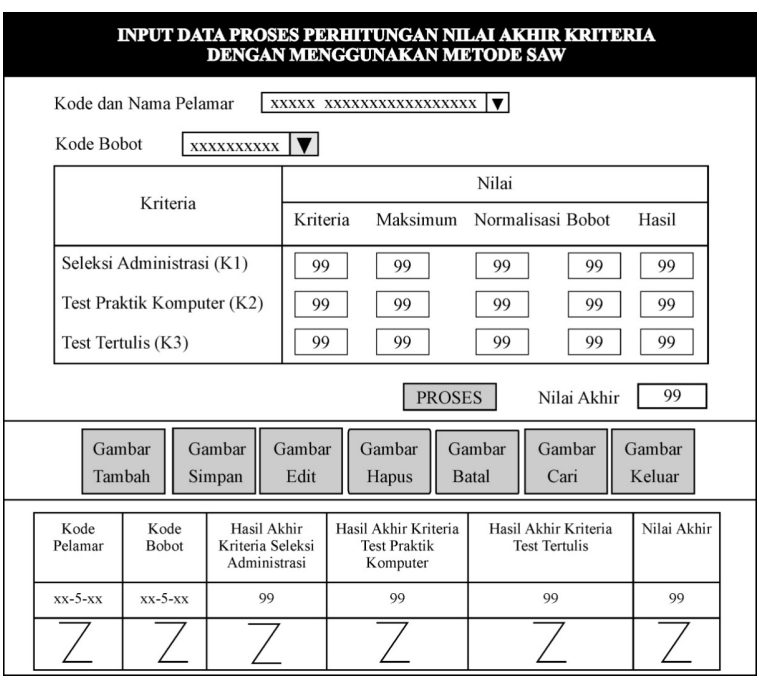

Gambar 17. Rancangan Input Data Nilai Akhir Metode SAW

\section{5) Rancangan Output}

Output yang dihasilkan dari Sistem Pendukung Keputusan Penerimaan Karyawan pada PT. Nusantara Sakti Ciptadana (NSC Finance) Kota Bengkulu Menggunakan Metote SAW adalah laporan output perorangan dan laporan output perangkingan.

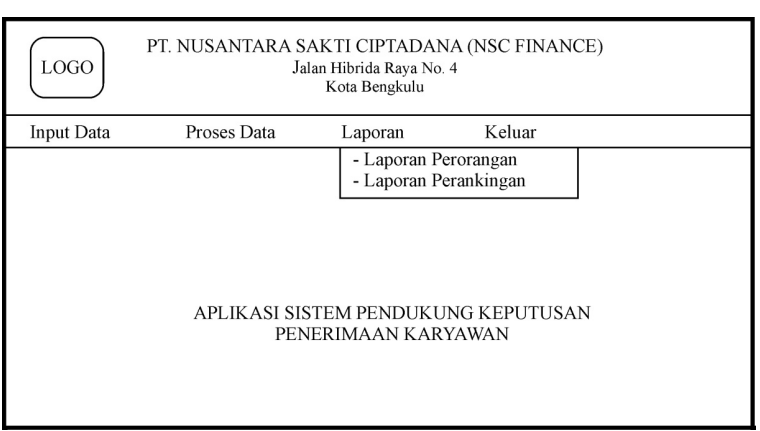

Gambar 18. Rancangan Input Proses Data

\section{HASIL DAN PEMBAHASAN}

\section{A. Menu Login}

Menu login merupakan tampilan yang terdiri dari kolom user name dan kolom password, kolom user name untuk memasukan nama pengguna Sistem Pendukung Keputusan Penerimaan Karyawan pada PT. Nusantara Sakti Ciptadana (NSC Finance) Kota Bengkulu Menggunakan Metode SAW.

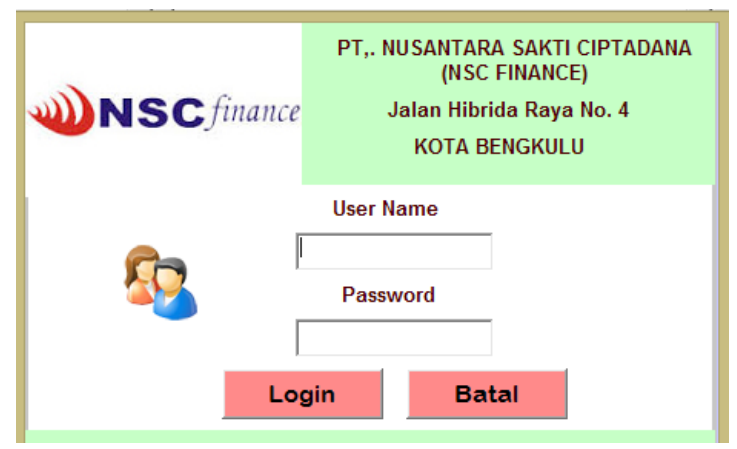

Gambar 19. Tampilan Menu Login

\section{B. Menu Utama}

Isi dari menu utama terdiri dari menu input data, menu proses, menu laporan dan menu keluar. 


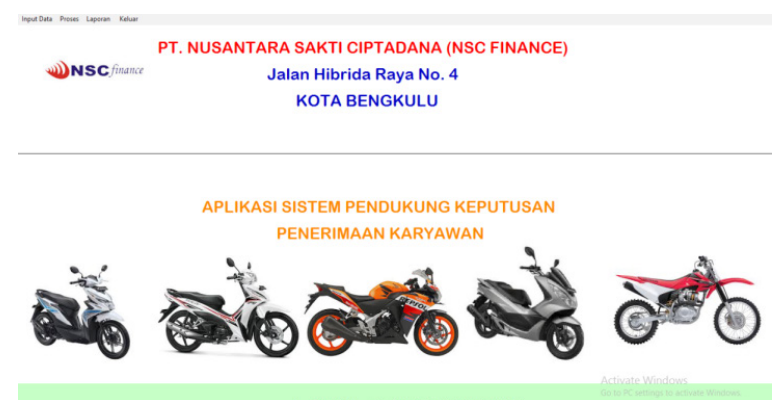

Gambar 20. Tampilan Menu Utama

\section{Tampilan Menu Input Data \\ 1) Menu Input Data Admin}

Pada menu data admin terdapat kolom user name dan kolom password dan dilengkapi juga dengan tombol tambah, tombol simpan, tombol edit, dan tombol keluar.

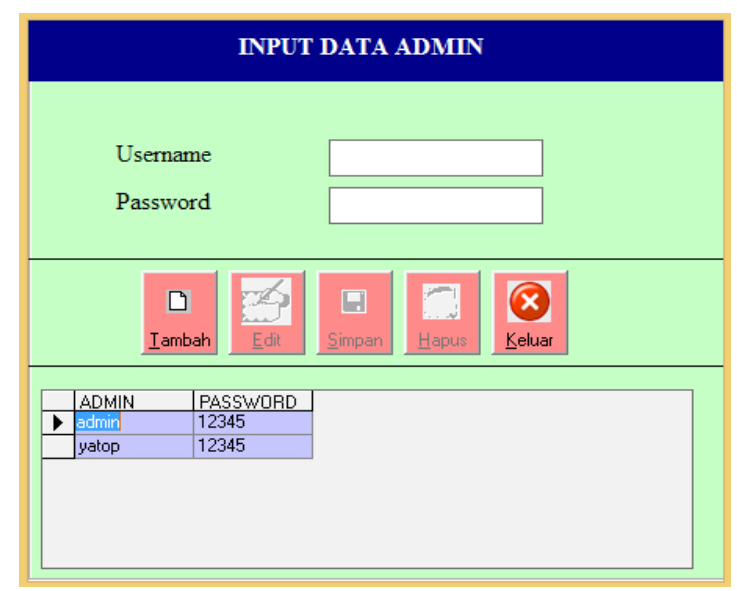

Gambar 21. Tampilan Menu Data Admin

\section{2) Tampilan Menu Input Data Pelamar}

Pada tampilan menu input data pelamar terdapat kolom kode pelamar, nama pelamar, jenis kelamin, tempat lahir, tanggal lahir, usia, status, pendidikan terakhir, alamat, nomor telephone dan kolom tujuan bagian lamaran. Field kode lamaran merupakan field kunci yang digunakan untuk menampilkan kembali field-field yang telah tersimpan sebelumnya. Tampilan menu input data pelamar dapat dilihat pada Gambar 22.

\section{3) Tampilan Menu Input Data Nilai Kriteria}

Menu input data Nilai kriteria terdiri dari menu input data kriteria administrasi, menu input data nilai kriteria praktik kompuer dan tampilan menu input data nilai kriteria test tertulis. Tampilan menu input data nilai kriteria disajikan dengan tampilan menu pilihan seperti terlihat pada Gambar 23.

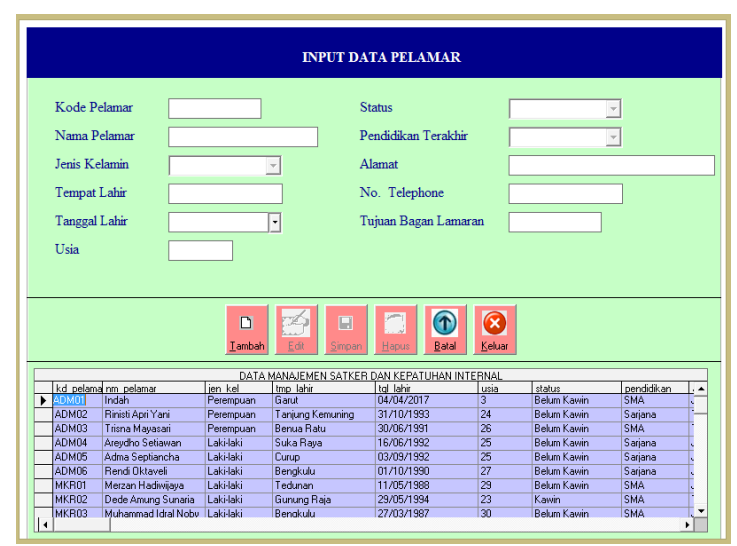

Gambar 22. Tampilan Menu Input Data Pelamar

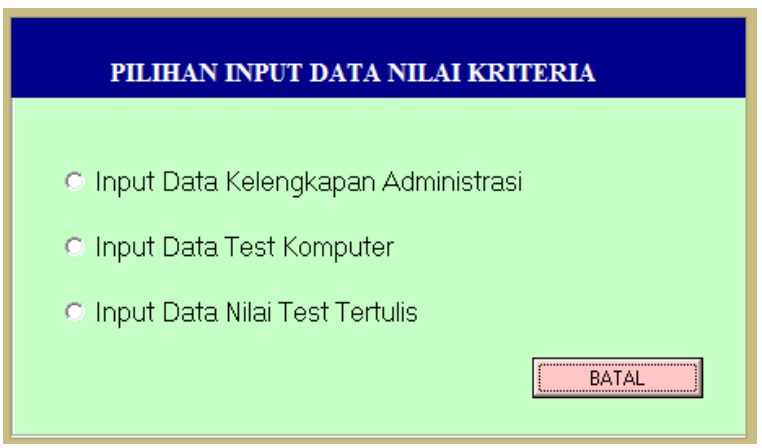

Gambar 23. Tampilan Menu Pilihan Input Data

\section{Kriteria}

\section{4) Menu input Data Nilai Kriteria Kelengkapan Administrasi}

Menu input data kriteria kelengkapan administrasi terdapat kolom kode pelamar, checkbox pilihan persyaratan memiliki ijazah sesuai persyaratan, checkbox pilihan persyaratan memiliki ijazah tidak sesuai persyaratan, checkbox pilihan persyaratan memiliki pengalaman kerja, checkbox pilihan persyaratan memiliki sertifikat komputer serta kolom akumulasi penilaian kriteira kelengkapan administrasi. Selain itu juga dilengkapi dengan tombol proses, tombol tambah, tombol simpan, tombol edit, tombol hapus, tombol batal, tombol cari dan tombol keluar. Tampilan menu input data nilai kriteria kelengkapan administrasi dapat dilihat pada Gambar 24. 


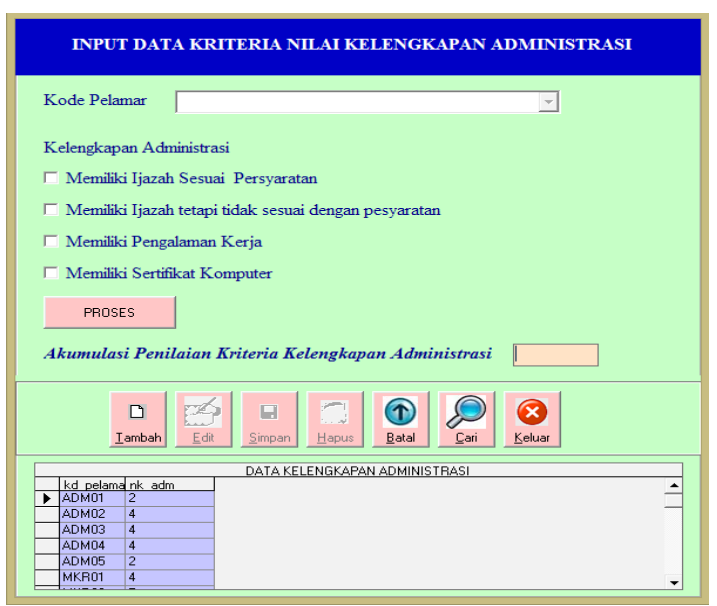

Gambar 24. Tampilan Menu Input Data Nilai Kriteria Kelengkapan Administrasi

\section{5) Menu input Data Nilai Kriteria Praktik Kom- puter}

Menu input data nilai kriteria praktik komputer menampilkan kolom kode pelamar, pilihan hasil test tidak menuaskan, pilihan hasil test kurang memuaskan, pilihan hasil test cukup memuaslan, pilihan hasil test memuaskan, dan pilihan hasil test sangat memuaskan serta kolom akumulasi penilaian kriteria praktik komputer. Selain itu juga dilengkapi dengan tombol proses, tombol tambah, tombol simpan, tombol edit, tombol hapus, tombol batal, tombol cari dan tombol keluar. Tampilan menu input data nilai kriteria praktik komputer dapat dilihat pada Gambar 25.

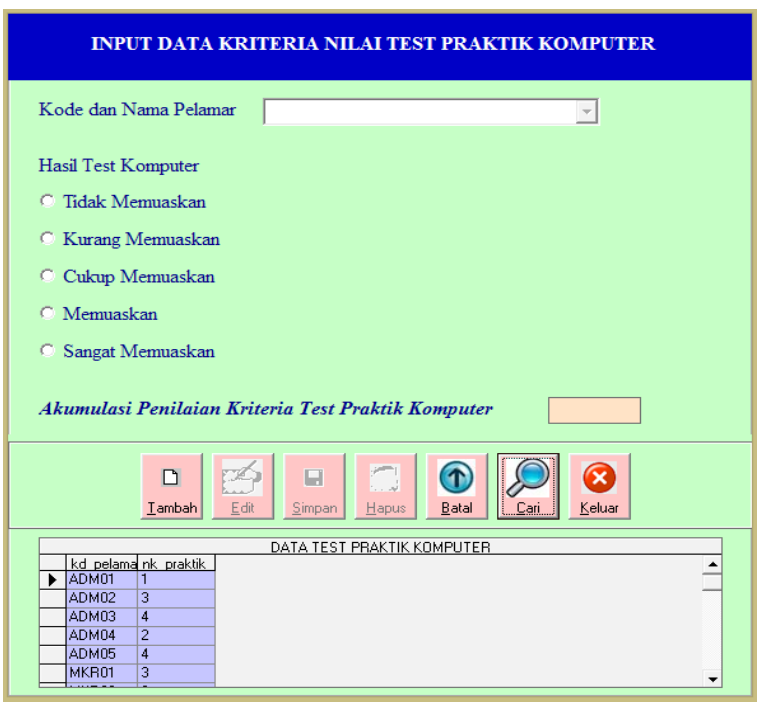

Gambar 25. Tampilan Menu Input Data Nilai Kriteria Praktik Komputer

\section{6) Menu input Data Nilai Kriteria Test Tertulis}

Menu input data nilai kriteria test tertulis menampilkan kolom kode pelamar, jumlah soal, jawaban benar, nilai akhir dan kolom akumulasi penilaian kriteria kriteria test tertulis. Selain itu juga dilengkapi dengan tombol tambah, tombol simpan, tombol edit, tombol hapus, tombol batal, tombol cari dan tombol keluar. Tampilan menu input data nilai kriteria test tertulis dapat dilihat pada Gambar 26.

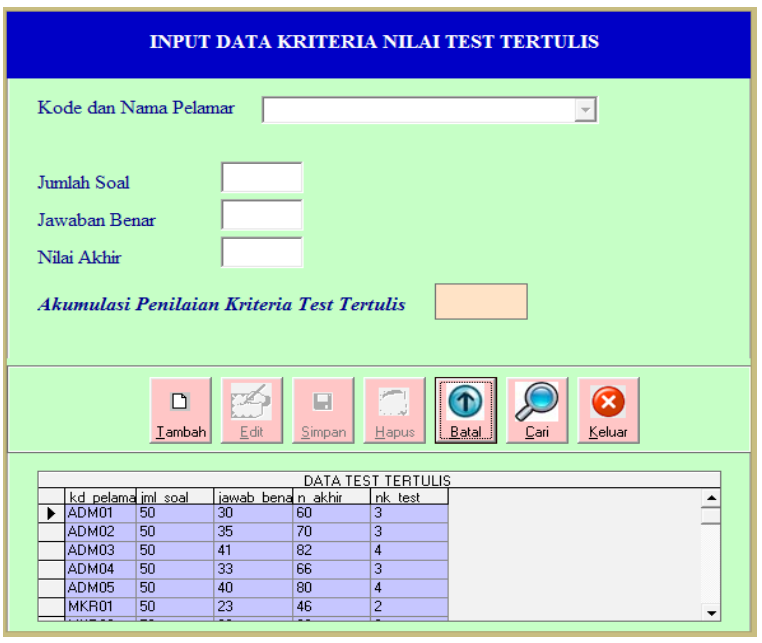

Gambar 26. Tampilan Menu Input Data Nilai Kriteria Test Tertulis

\section{7) Tampilan Menu Input Data Bobot}

Menu data nilai bobot menampilkan kolom kode bobot, nilai bobot kelengkapan administrasi, nilai bobot praktik komputer dan nilai bobot test tertulis. Tampilan menu input data nilai bobot dapat dilihat pada Gambar 27.

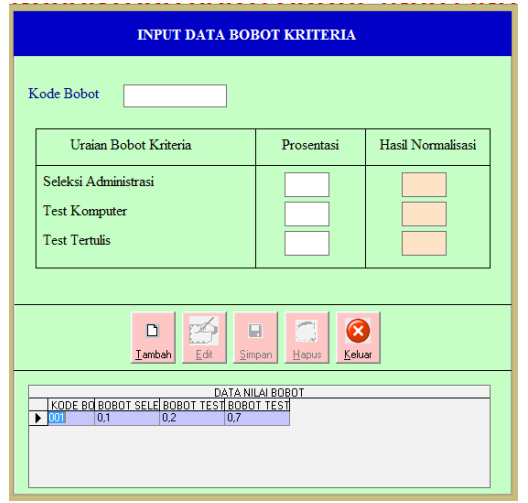

Gambar 27. Tampilan Menu Input Data Nilai Bobot 


\section{Tampilan Menu Proses Penentuan Nilai} Akhir

Pada tampilan menu proses perhirtungan nilai akhir menampilkan kolom kode pelamar, kolom kode bobot, nilai kriteria kelangkapan administrasi, nilai kriteria praktik komputer, nilai kriteria test tertulis, nilai maksimum kelengkapan administrasi, nilai maksimum praktik komputer, nilai maksimum test tertulis, nilai bobot kelengkapan administrasi, nilai bobot praktik komputer, nilai bobot test tertulis, nilai normalisasi kelengkapan administrasi, nilai normalisasi praktik komputer, nilai normalisasi test tertulis, nilai hasil akhir kelengkapan administrasi, nilai hasil akhir praktik komputer, nilai hasil akhir test komputer dan nilai akhir kriteria. Tampilan menu input data proses perhitungan nilai akhir disajikan pada gambar 28.

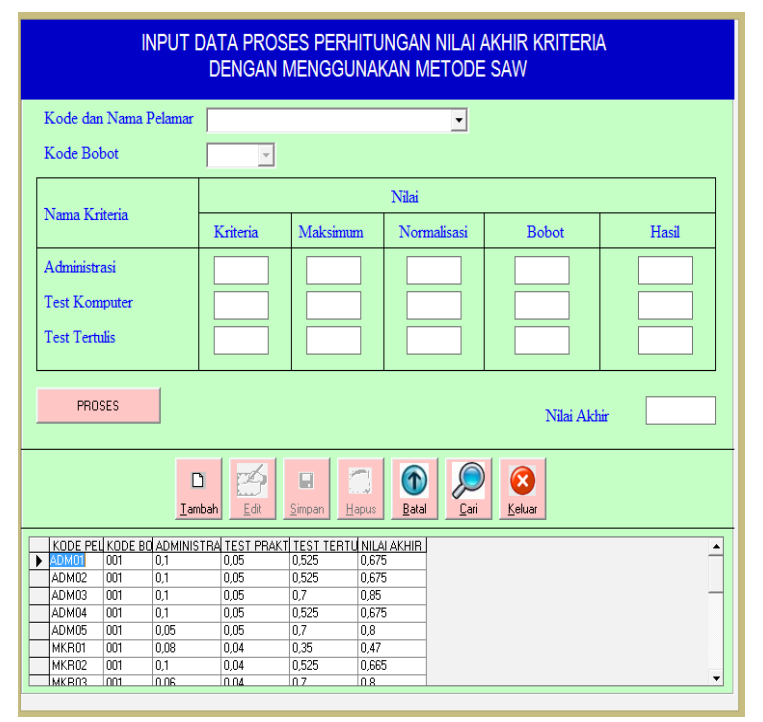

Gambar 28. Tampilan Menu Proses Perhitungan Nilai Akhir

\section{E. Tampilan Laporan}

\section{1) Hasil Seleksi Perorangan}

Tampilan Laporan hasil seleksi perorangan menampilkan halaman yang berisikan data hasil perorangan bagian administrasi dan bagian marketing yang ditampilkan berdasarkan Kode Lamaran. Tampilan interface dan cetak laporan hasil seleksi perorangan bagian Administrasi dan Bagian Marketing dapat dilihat pada Gambar 29, Ga,bar 30 dan Gambar 31.

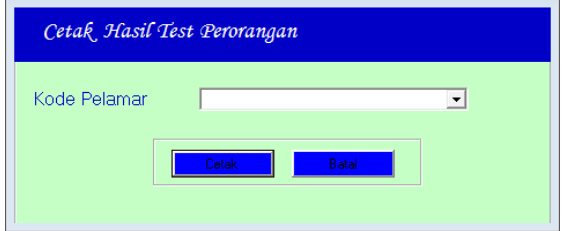

Gambar 29. Tampilan Interface Laporan Hasil Seleksi Peorangan

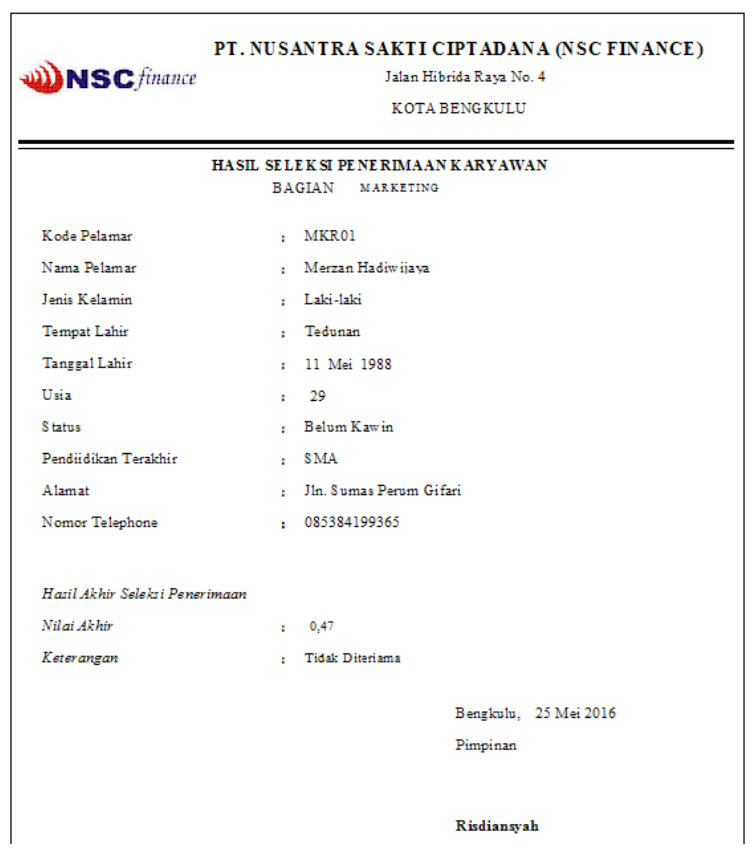

Gambar 30. Tampilan Laporan Hasil Perorangan Bagian Administrasi

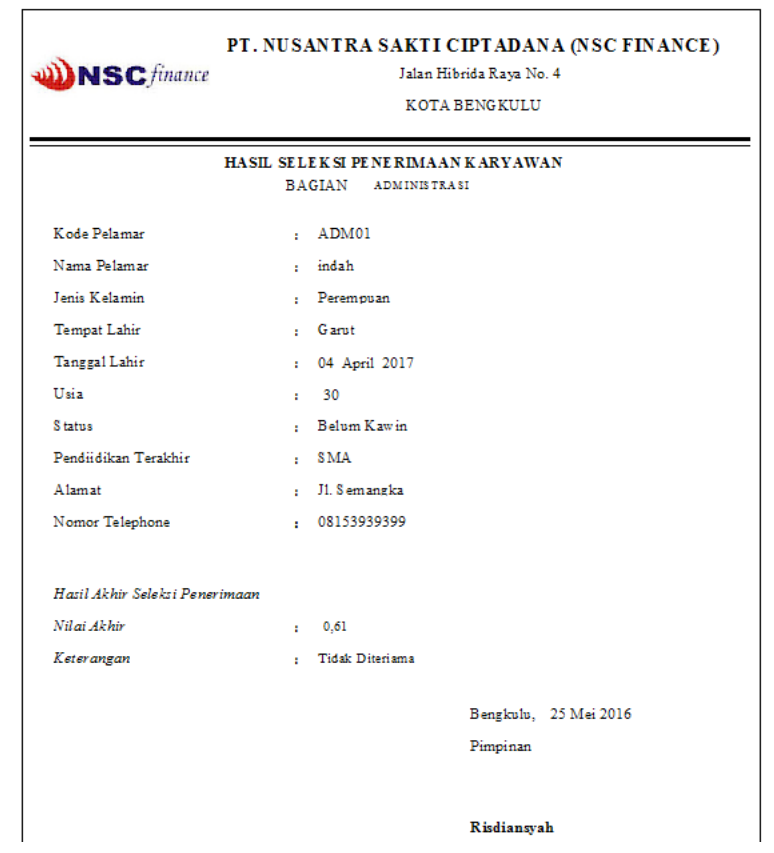

Gambar 31. Tampilan Laporan Hasil Perorangan Bagian Marketing 


\section{2) Hasil Perankingan}

Laporan hasil perankingan menampilkan hasil laporan perankingan bagian administrasi dan hasil laporan perankingan bagian marketing. Laporan hasil perankingan menampilkan seluruh pelamar yang mengikuti proses seleksi penerimaan karyawan di PT. Honda. Tampilan laporan hasil perangkingan seleksi penerimaan calon karyawan ditampilkan berdasarkan interface cetak laporan perangkingan. Tampilan interface cetak laporan perankingan, hasil laporan perankingan bagian administrasi dan bagian marketing dapat dilihat pada gambar 32, 33, dan 34 .

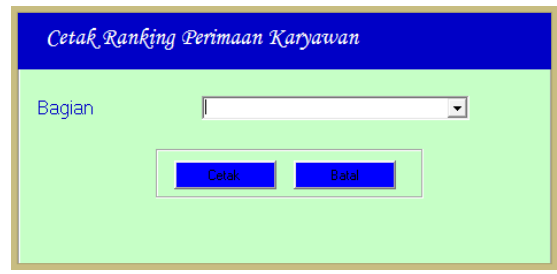

Gambar 32. Tampilan Interface Cetak Laporan Perankingan

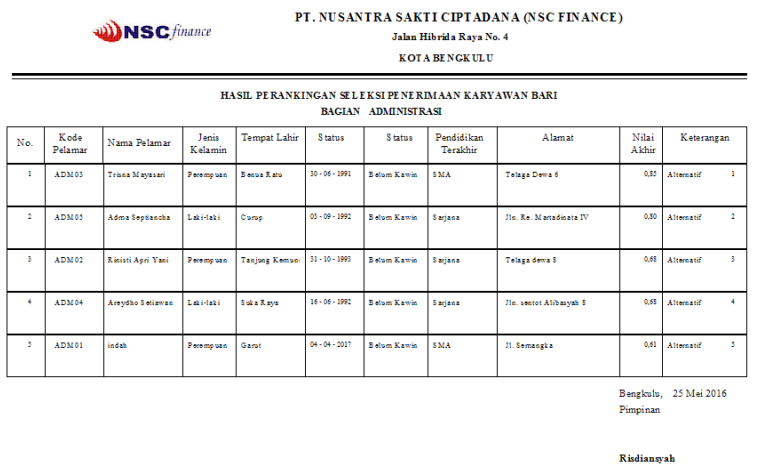

Gambar 33. Tampilan Laporan Perankingan Bagian Administrasi

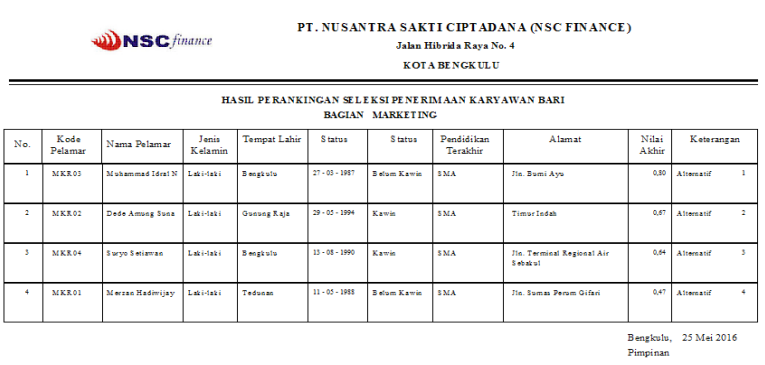

Gambar 34. Tampilan Laporan Perankingan Bagian Marketing

\section{KESIMPULAN}

1. Sistem Pendukung Keputusan Penerimaan Karyawan pada PT. Nusantara Sakti Ciptadana (NSC Finance) Kota Bengkulu memungkinkan pemakai untuk mengakses data file-file (tabel) yang dirancang dalam pengembangan Sistem Pendukung Keputusan Penerimaan Karyawan.

2. Pemodelan sistem dalam pengembangan Sistem Pendukung Keputusan Penerimaan Karyawan pada PT. Nusantara Sakti Ciptadana (NSC Finance) Kota Bengkulu Menggunakan Metode SAW ini adalah dengan mengembangkan aliran data yang akan diproses menjadi informasi dan aliran distribusi yang dibuat secara sederhana dengan menggunakan Diagram Kontek, Diagram Arus Data (DFD) level 0 sampai level 3 dan juga menggunakan Entity Relationalship Diagram (ERD).

\section{DAFTAR PUSTAKA}

Fathansyah, 2012, Basis Data,:Informatika, Bandung

Hermawan. 2004. Membangun Decision Support System : Andi. Yogyakarta.

Shalahuddin, 2011, Modul Rekayasa Perangkat Lunak, Modula, Bandung.

Sutarbi, 2012, Analisis Sistem Informasi : Andi. Yogyakarta.

Subari \& Susanto, 2008, Panduan Lengkap Pemrograman Visual Basic 6.0. : Publisher, Jakarta

Syamsi, Ibnu, 2000, Pengambilan Keputusan dan Sistem Informasi : Bumi Aksara, Jakarta. Supriyono, 2007, Pengantar Teknologi Informasi: Salemba Infotexk, Jakarta. 